\title{
PERKECAMBAHAN BENIH JAGUNG (Zea mays L.) PADA BERBAGAI UMUR PANEN BENIH DAN KELEMBABAN MEDIA TANAM
}

\section{GERMINATION CORN SEED (Zea mays L.) AT THE VARIOUS HARVEST AGES OF THE SEED AND THE HUMIDITY OF VARIOUS TRANSPLANTING MEDIUM}

\author{
Vilma Victa Rikumahu1), J. Pongoh²) dan J.M. Paulus ${ }^{2)}$ \\ 1)Dinas Pertanian, Kehutanan dan Ketahanan Pangan Kota Bitung \\ e-mail : vilmavictarikumahu@gmail.com \\ 2)Fakultas Pertanian Unsrat Manado
}

\begin{abstract}
Research has been implemented as of July 2012, in the BPSB Laboratory of North Sulawesi Province i.e.: 1) to test the seed lacking in vigour during the Random Complete Design with three treatments of the various harvest ages, i.e. U1 (90 dasy), U2 (100 days) and U3 (110 days) treatments repeated four times; 2 ) in the greenhouse to see the amount of the normal, sprouts abnormal, seeds, hard seed and dead, shoot root ratio by using the Random Completed Design with two factors, respectively are : factorial in complete factors of the first different age harvest U1 (90 days), U2 (100 days) and U3 (110 days), the second factor granting of the water with different capacity P1 $(3600 \mathrm{ml})$, P2 $(2700 \mathrm{ml})$, P3 $(1800 \mathrm{ml})$ and P4 $(900 \mathrm{ml})$. Data analysis were found by the various analysis, however if there are different results, it would continue on the Smallest Significant Test. The results showed that, Electric Power Conductivity (EPC) affected by the age of harvest seed corn. The highest EPC at the harvest ages of 90 days and the lowest at 100 days and 110 days. It would be shown that the great value of EPC, the smallest amount of germination. There is no interaction between the age of abnormal seeds, hard seed die, shoot root ratio and high sprouts, but single factor treatment of harvest age and media planting humidity were significantly effected toward sprout normal, abnormal seed, hard seed die, shoot root ratio and high sprouts.
\end{abstract}

Keywords : corn seed, harvest ages, humidity

\section{ABSTRAK}

Penelitian dilaksanakan sejak bulan Juli 2012, penelitian pertama di Laboratorium Balai Penelitian dan Sertifikasi Benih (BPSB) Provinsi Sulawesi Utara, untuk menguji vigor benih menggunakan Rancangan Acak Lengkap dengan tiga perlakuan umur panen yang berbeda: U1 (90 Hari), U2 (100 Hari) dan U3 (110 hari) perlakuan diulang empat kali. Penelitian kedua di Rumah Kaca untuk melihat jumlah kecambah normal, abnormal, benih keras,benih mati dan nisbah pupus akar menggunakan Rancangan Acak Lengkap disusun secara faktorial dengan 2 faktor masing-masing adalah : faktor pertama : Umur Panen yang berbeda, U1 (90 Hari), U2 (100 Hari) dan U3 (110 hari). faktor kedua pemberian air dengan kapasitas yang berbeda, P1 (3600 ml), P2 (2700 ml), P3 (1800 ml) dan P4 (900 ml). Data yang diperoleh menggunakan analisa ragam dan jika terdapat perbedaan perlakuan dilanjutkan dengan uji Beda Nyata Terkecil (BNT). Hasil penelitian yang didapat adalah; Daya hantar listrik (DHL) dipengaruhi oleh umur panen benih jagung, DHL tertinggi pada umur panen 90 hari dan yang terendah umur panen 100 dan 110 hari. Hal ini menunjukan bahwa semakin besar nilai DHL semakin kecil jumlah perkecambahan. Tidak terdapat interaksi antara umur panen benih dan kelembaban media tanam terhadap jumlah kecambah normal, abnormal, benih keras, benih mati, nisbah pupus akar dan tinggi kecambah tetapi secara tunggal faktor perlakuan umur panen dan kelembaban media tanam berpengaruh nyata terhadap kecambah normal, abnormal, benih keras, benih mati, nisbah pupus akar dan tinggi kecambah.

Kata kunci : benih jagung, umur panen, kelembaban 


\section{PENDAHULUAN}

Benih merupakan komponen terkecil dari seluruh sistem ekonomi pertanian, namun cukup memegang peranan penting karena menentukan hasil/produksi dari tanaman. Hertiningsih (2009) mengemukakan bahwa benih yang dipanen sebelum masak fisiologis belum memliki cadangan makanan yang cukup dan keadaan embrio belum sempurna sedangkan yang masak fisiologis embrio telah terbentuk secara sempurna serta telah memiliki cadangan makanan yang cukup. Waktu panen dan cara pasca panen akan menentukan kualitas benih sebelum disimpan, apabila di panen sebelum masak fisiologis dicapai tidak mempunyai viabilitas yang tinggi bahkan tidak akan berkecambah.

Menurut Kartasapoetra (2003), mutu tertinggi benih diperoleh saat benih mencapai masak fisiologis karena pada saat itu benih memiliki berat kering, viabilitas dan vigor yang maksimal, sedangkan Purwadi (2011) mengatakan bahwa tingkat kemasakan benih adalah saat dimana bobot kering maksimal benih tercapai, bahwa viabilitas benih yang sudah lewat masak fisiologis lebih rendah dari benih yang sudah masak fisiologis. Benih yang dipanen pada saat mencapai masak fisiologis mempunyai daya berkecambah maksimal karena embrio sudah terbentuk sempurna, sedangkan benih yang dipanen setelah masak fisiologis akan mempunyai daya berkecambah rendah. Air merupakan salah satu syarat penting bagi berlangsungnya proses perkecambahan benih. Dua faktor penting yang mempegaruhi penyerapan air oleh benih adalah sifat dari benih itu sendiri terutama kulit pelindungnya dan jumlah air yang tersedia pada medium di sekitarnya. Air merupakan faktor penting karena biji berada dalam keadaan terdehidrasi. Secara normal biji mengandung air antara 5 hingga $20 \%$ dari berat totalnya dan harus menyerap sejumlah air sebelum perkecambahan di mulai (Kartasapoetra, 2003).

Kekurangan air adalah faktor eksternal yang menyebabkan perubahan yang tidak diinginkan atau merusak terhadap mutu jika tanaman atau bagian tanaman dihadapkan terhadap stres pada lama waktu dan intensitas mencukupi, kekurangan dan kelebihan air merupakan suatu keadaan yang tidak normal dimana tanaman mengalami suatu cekaman tertentu yang berasal dari luar tubuhnya yang dapat berupa faktor biotik maupun abiotik yang diberikan kepada tanaman jagung (Purwadi, 2011).

Kelebihan air menyebabkan aerasi tanah terganggu yang dapat mengakibatkan kerusakan akar akibat kekurangan oksigen $\left(\mathrm{O}_{2}\right)$. Kerusakan pada pucuk bukan kerusakan primer melainkan kerusakan sekunder karena akar rusak, hal ini berpengaruh pada pertumbuhan tanaman. Jagung yang tumbuh pada $4 \%$ oksigen menunjukan berkurangnya produksi bahan kering sebesar $32 \%$, fotosintesis berkurang karena hambatan produk (Haryati, 2008).

Berdasarkan uraian di atas maka perlu untuk diadakan penelitian guna mengetahui perkecambahan benih jagung (Zea mays L.) pada berbagai umur panen dan kelembaban media tanam.

Penelitian ini bertujuan untuk mengetahui interaksi perkecambahan benih jagung (Zea mays L.) pada berbagai umur panen dan kelembaban media tanam, perkecambahan benih jagung (Zea mays L.) pada berbagai umur panen, dan perkecambahan benih jagung (Zea mays L.) pada berbagai kelembaban media tanam.

\section{METODE PENELITIAN}

Penelitian ini dilaksanakan di Laboratorium Balai Penelitian dan Sertifikasi Benih (BPSB) Provinsi Sulawesi Utara dan rumah kaca (green house). Penelitian berlangsung pada bulan Juli sampai dengan Agustus 2012. Bahan dan Alat yang digunakan yaitu benih tanaman jagung varietas Jaya 2, pasir, air, air aquabides, aluminium foil, tissue, gelas ukur, gelas, botol pencuci, label, timbangan kasar, timbangan analitik, timbangan, sprayer, alat pengukur kadar air (moisture meter), termo-hygrometer, konduktivity meter, oven, termometer, sekop, meteran.

Penelitian pertama dilaksanakan di laboratorium dengan menggunakan Rancangan Acak Lengkap dengan perlakuan 3 (tiga) umur panen (U ): U1 (Umur panen 90 hari), U2 (Umur 
panen 100 hari), U3 (Umur panen 110 hari) Setiap perlakuan diulang sebanyak 4 (empat) kali

Penelitian kedua dilaksanakan di rumah kaca (green house) dengan menggunakan Rancangan Acak Lengkap dengan perlakuan disusun secara faktorial dengan 2 faktor yaitu : Faktor pertama benih jagung dengan umur panen (U) terdiri dari : U1 (Umur panen 90 hari), U2 (Umur panen 100 hari), U3 (Umur panen 110 hari)

Faktor kedua kelembaban media tanam (P) terdiri dari : P1 = Kapasitas lapang setara dengan pemberian air $3600 \mathrm{ml}, \mathrm{P} 2=75 \%$ Kapasitas lapang setara dengan pemberian air $2700 \mathrm{ml}, \mathrm{P} 3=$ $50 \%$ Kapasitas lapang setara dengan pemberian air $1800 \mathrm{ml}, \mathrm{P} 4=25 \%$ Kapasitas lapang setara dengan pemberian air $900 \mathrm{ml}$.

Masing-masing perlakuan diulang empat kali. Variabel yang diamati terdiri dari : 1) Pengujian DHL untuk menguji vigor benih dan 2) Jumlah kecambah yang terdiri dari : Kecambah normal, kecambah abnormal, benih keras, benih mati, tinggi kecambah (cm) dan nisbah pupus akar (gr).

\section{Prosedur Kerja}

\section{Tahap Pelaksanaan Pengujian di Laboratorium}

Persiapan wadah/gelas sebanyak 18 buah yang sudah dicuci bersih untuk mencegah cendawan, 12 gelas untuk perlakuan dan 6 gelas untuk air blangko yang ditutupi dengan kertas aluminium foil, Siapkan benih yang sudah ditimbang untuk masing-masing perlakuan. Ukur air aquabides dengan gelas ukur sebanyak $250 \mathrm{ml}$ dan diisi di semua gelas perlakuan berjumlah 18 gelas, biarkan selama 24 jam di dalam ruangan dengan temperatur $20-25^{\circ} \mathrm{C}$, setelah 24 jam rendam benih dalam wadah gelas yang berisi air aguabides sedangkan larutan blangko dibiarkan kosong sebagai air penetral yang digunakan untuk alat konduktivity meter. Ukur nilai DHL setiap perlakuan dengan menggunakan konduktivity meter.

\section{Tahap Pelaksanaan Penelitian di Rumah Kaca (green house)}

Persiapan wadah/bak plastik $45 \times 35 \mathrm{~cm}$ sebanyak 48 buah di rumah kaca. Siapkan benih dari masing-masing perlakuan, pasir dicuci dijemur di panas matahari hingga kering, isi ke dalam wadah plastik sesuai takaran $6 \mathrm{~kg}$ yang ada di 48 wadah plastik. Buat lobang tanam sedalam $1 \mathrm{~cm}$, lobang di semua bak plastik yang ada kemudian tanam setiap bak dengan 100 benih jagung Jaya 2 . Penyiraman dilakukan sekali sesudah tanam dengan sprayer dan melakukan pengamatan daya berkecambah, tinggi kecambah, suhu dan kelembaban media tanam selama tujuh hari.

Data yang diperoleh, baik perlakuan pada benih jagung di laboratorium maupun di rumah kaca, menggunakan analisa ragam dan jika terdapat perbedaan antar perlakuan dilanjutkan dengan uji Beda Nyata Terkecil (BNT) pada taraf signifikasi $5 \%$.

\section{HASIL DAN PEMBAHASAN}

\section{Daya Hantar Listrik (DHL)}

Pengamatan Daya Hantar Listrik (DHL) terhadap perlakuan umur panen benih jagung dapat dilihat pada Tabel 1 dimana DHL tertinggi pada perlakuan umur panen 90 hari dengan nilai 11,10 dan nilai $\mathrm{DHL}$ terendah pada perlakuan umur panen 110 hari dengan nilai 6,57 . Hal ini menunjukan bahwa semakin besar nilai daya hantar listrik berarti semakin rendahnya mutu benih itu. Salah satu cara untuk menentukan mutu suatu benih terutama mutu fisiologis benih adalah melalui uji daya hantar listrik (DHL). Menurut Mathew dan Powell (2006) dalam Brillianti (2009), prinsip yang digunakan dalam uji DHL adalah perubahan organisasi membran sel yang terjadi selama perkembangan benih sebelum benih masak fisiologis, pengeringan sebelum panen dan selama imbibisi sebelum perkecambahan. Salah satu mutu fisiologis adalah matang fisiologis. Pada saat matang fisiologis akumulasi bahan kering (dry matter) dan bahan kimia yang terlibat dalam perkecambahan sudah mencapai maksimal. Umur panen berpengaruh nyata terhadap Daya hantar Listrik (DHL). 
Tabel 1. Daya Hantar Listrik (DHL) pada Berbagai Umur Panen Benih Jagung

(Table 1. Conductivity Electric Power (DHL) at the Various Harvest Ages of Corn Seed)

\begin{tabular}{cc}
\hline Perlakuan Umur Panen Benih Jagung & Rata-rata \\
\hline 90 hari & $11,11 \mathrm{c}$ \\
100 hari & $7,02 \mathrm{~b}$ \\
110 hari & $6,57 \mathrm{a}$ \\
\hline BNT 5\% & 0,45
\end{tabular}

Keterangan : Angka yang diikuti dengan huruf yang sama tidak berbeda nyata berdasarkan uji BNT 5\%.

Tabel 2. Jumlah Kecambah Normal pada Berbagai Umur Panen Benih Jagung

(Table 2. The Amount of Normalized Sprout at the Various Harvest Ages of Corn Seed)

\begin{tabular}{cc}
\hline Perlakuan Umur Panen Benih Jagung & Rata-rata \\
\hline 90 hari & $86,63 \mathrm{a}$ \\
100 hari & $93,44 \mathrm{~b}$ \\
110 hari & $94,50 \mathrm{c}$ \\
\hline BNT 5\% & 3,97
\end{tabular}

Keterangan : Angka yang diikuti dengan huruf yang sama pada kolom yang sama berbeda nyata berdasarkan uji BNT 5\%.

Tabel 3. Jumlah Kecambah Normal pada Berbagai Kelembaban Media Tanam

(Table 3. The Amount of Normalized Sprout at the Hhumidities of Various Transplanting Medium)

\begin{tabular}{cc}
\hline Perlakuan Kelembaban Media Tanam & Rata-rata \\
\hline Kapasitas lapang setara pemberian air $3600 \mathrm{ml}$ & $94,17 \mathrm{c}$ \\
$75 \%$ Kapasitas lapang setara pemberian air $2700 \mathrm{ml}$ & $93,00 \mathrm{~b}$ \\
$50 \%$ Kapasitas lapang setara pemberian air $1800 \mathrm{ml}$ & $92,67 \mathrm{~b}$ \\
$25 \%$ Kapasitas lapang setara pemberian air $900 \mathrm{ml}$ & $86,58 \mathrm{a}$ \\
\hline
\end{tabular}

BNT $5 \%$

Keterangan : Angka yang diikuti dengan huruf yang sama pada kolom yang sama berbeda nyata berdasarkan uji BNT 5\%.

\section{Jumlah Kecambah \\ Jumlah Kecambah Normal}

Selanjutnya hasil uji BNT yang disajikan pada Tabel 2 dan Tabel 3, diperoleh data rata-rata jumlah kecambah normal terendah pada perlakuan umur panen 90 hari dengan jumlah kecambah 86,63 dengan kapasitas lapang setara dengan pemberian air $3600 \mathrm{ml}$, jumlah kecambah normal terbanyak pada perlakuan umur panen jagung 110 hari yang tidak berbeda dengan umur panen benih jagung 100 hari perlakuan kapasitas air 100\%, $3600 \mathrm{ml}$ memberikan jumlah kecambah normal sebanyak 94,17 yang tidak berbeda nyata dengan perlakuan kapasitas air 75\%, $2700 \mathrm{ml}$ dan kapasitas air 50\%, $1800 \mathrm{ml}$ tetapi ketiga perlakuan di atas berbeda dengan perlakuan kapasitas air $25 \%$, $900 \mathrm{ml}$, tidak terdapat interaksi antara umur panen benih jagung dan kelembaban media tanam terhadap jumlah kecambah normal. Umur panen benih berpengaruh nyata terhadap jumlah kecambah normal dan kelembaban media tanam juga berpengaruh nyata terhadap jumlah kecambah normal.

Penelitian Hermawan (2011), dengan tujuan mengkaji pengaruh waktu panen terhadap hasil, daya berkecambah dan vigor benih cabe diperoleh hasil terbaik pada benih cabe yang diperoleh dari pemanenan cabai yang berwarna merah kecoklatan karena pada waktu itu cabai telah mengalami masak fisiologis. Benih bermutu dapat diperoleh dengan melakukan penanganan pasca panen yang tepat seperti : panen pada saat masak fisiologis, pengeringan benih hingga kadar air mencapai kadar air yang aman untuk disimpan, melakukan sortasi benih, serta penyimpanan 
dengan kemasan yang kedap udara dan bebas dari hama gudang (Rahmawati, 2003).

Hasil penelitian Murniati dkk. (2008), menunjukkan bahwa pemanenan buah pepaya untuk produksi benih sebaiknya dilakukan setelah buah 80 sampai $90 \%$ kuning di pohon karena buah yang dipanen pada 30 sampai $40 \%$ berwarna kuning mempunyai daya berkecambah dan kecepatan tumbuh nyata lebih rendah daripada benih yang dipanen setelah buah masak di pohon (80 sampai $90 \%$ berwarna kuning). Menurut Copeland dan Mc.Donald (2001) dalam Murniati $d k k$. (2008), benih yang telah matang fisiologis telah mempunyai cadangan makanan sempurna sehingga dapat menunjang pertumbuhan kecambah. Selanjutnya dikatakan bahwa tingkat kematangan benih dapat dicirikan dengan tingkat kematangan buahnya.

\section{Jumlah Kecambah Abnormal}

Pada Tabel 4 dan 5 dapat dilihat bahwa perlakuan berbagai umur panen benih jagung dan kelembaban media tanam berbeda nyata terhadap jumlah kecambah normal, tidak terdapat interaksi antara umur panen benih dan kelembaban media tanam terhadap jumlah kecambah abnormal.

Pada Tabel 4 dapat dilihat kecambah abnormal terbanyak pada perlakuan umur panen 90 hari yang berbeda dengan umur panen 100 dan 110 hari. Dari hasil uji BNT diperoleh data rata-rata tertinggi pada umur panen benih 90 hari sebanyak 6,38 sedangkan untuk kelembaban media tanam tertinggi pada $25 \%$ kapasitas lapang setara pemberian air $900 \mathrm{ml}$ dengan jumlah 5,33 dan ratarata terendah pada umur panen benih 110 hari sebanyak 1,44 yang tidak berbeda jauh dengan 100 hari dengan $75 \%$ dan $50 \%$ kapasitas lapang.

\section{Jumlah Benih Keras}

Pada Tabel 6 dan 7 dapat dilihat bahwa umlah benih keras tidak dipengaruhi oleh umur panen benih dan kelembaban media tanam baik interaksi maupun secara tunggal. Umur panen benih dan kelembaban media tanam tidak mempengaruhi benih keras sampai dengan 7 hari waktu pengujian benih.

Tabel 4. Jumlah Kecambah Abnormal pada Berbagai Umur Panen Benih Jagung

(Table 4. The Amount of Abnormally Sprout at the Various Harvest Ages of Corn Seed)

\begin{tabular}{ccc}
\hline & Perlakuan Umur Panen Benih Jagung & Rata-rata \\
\hline 90 hari & $6,38 \mathrm{c}$ \\
& 100 hari & $2,69 \mathrm{~b}$ \\
110 hari & $1,44 \mathrm{a}$ \\
\hline BNT 5\% & 1,51 \\
\hline \multirow{2}{*}{ Keterangan $:$} & Angka yang diikuti dengan huruf yang sama pada kolom yang sama berbeda nyata \\
& berdasarkan uji BNT 5\%. &
\end{tabular}

Tabel 5. Jumlah Kecambah Abnormal pada Berbagai Kelembaban Media Tanam

(Table 5. The Amount of Abnormally Sprout at the Humidity of Transplanting Medium)

\begin{tabular}{cc}
\hline Perlakuan Kelembaban Media Tanam & Rata-rata \\
\hline Kapasitas lapang setara pemberian air $3600 \mathrm{ml}$ & $2,58 \mathrm{a}$ \\
$75 \%$ Kapasitas lapang setara pemberian air $2700 \mathrm{ml}$ & $3,17 \mathrm{a}$ \\
$50 \%$ Kapasitas lapang setara pemberian air $1800 \mathrm{ml}$ & $2,92 \mathrm{a}$ \\
$25 \%$ Kapasitas lapang setara pemberian air $900 \mathrm{ml}$ & $5,33 \mathrm{~b}$ \\
\hline BNT $5 \%$ & 1,74
\end{tabular}

Keterangan : Angka yang diikuti dengan huruf yang sama pada kolom yang sama berbeda nyata berdasarkan uji BNT 5\%. 
Tabel 6. Jumlah Benih Keras pada Berbagai Umur Panen Benih

(Table 6. The Amount of Hard Seed at the Various Harvest Ages of Corn Seed)

\begin{tabular}{rc}
\hline Perlakuan Umur Panen Benih Jagung & Rata-rata \\
\hline 90 hari & 0,38 \\
100 hari & 1,00 \\
110 hari & 0,88 \\
\hline
\end{tabular}

Tabel 7. Jumlah Benih Keras pada Berbagai Kelembaban Media Tanam

(Table 7. The Amount of Hard Seed at the Humidity of Transplanting Medium)

\begin{tabular}{cc}
\hline Perlakuan Kelembaban Media Tanam & Rata-rata \\
\hline Kapasitas lapang setara pemberian air $3600 \mathrm{ml}$ & 0,25 \\
$75 \%$ Kapasitas lapang setara pemberian air $2700 \mathrm{ml}$ & 0,50 \\
$50 \%$ Kapasitas lapang setara pemberian air $1800 \mathrm{ml}$ & 0,67 \\
$25 \%$ Kapasitas lapang setara pemberian air $900 \mathrm{ml}$ & 1,58 \\
\hline
\end{tabular}

Tabel 8. Jumlah Benih Mati pada Berbagai Umur Panen Benih Jagung

(Table 8. The Amount of Dead Seed at the Various Harvest Ages of Corn Seed)

\begin{tabular}{rc}
\hline Perlakuan Umur Panen Benih Jagung & Rata-rata \\
\hline 90 hari & $6,63 \mathrm{~b}$ \\
100 hari & $2,94 \mathrm{a}$ \\
110 hari & $3,19 \mathrm{a}$ \\
\hline BNT 5\% & 2,27
\end{tabular}

Keterangan : Angka yang diikuti dengan huruf yang sama pada kolom yang sama berbeda nyata berdasarkan uji BNT 5\%.

Tabel 9. Jumlah Benih Mati pada Berbagai Kelembaban Media Tanam

(Table 9. The Amount of Dead Seeds at the Humidity of Transplanting Medium)

\begin{tabular}{cc}
\hline Perlakuan Kelembaban Media Tanam & Rata-rata \\
\hline Kapasitas lapang setara pemberian air $3600 \mathrm{ml}$ & $3,00 \mathrm{a}$ \\
$75 \%$ Kapasitas lapang setara pemberian air $2700 \mathrm{ml}$ & $3,33 \mathrm{~b}$ \\
$50 \%$ Kapasitas lapang setara pemberian air $1800 \mathrm{ml}$ & $3,83 \mathrm{~b}$ \\
$25 \%$ Kapasitas lapang setara pemberian air $900 \mathrm{ml}$ & $6,83 \mathrm{c}$ \\
\hline
\end{tabular}

\section{BNT $5 \%$}

2,62

Keterangan : Angka yang diikuti dengan huruf yang sama pada kolom yang sama berbeda nyata berdasarkan uji BNT 5\%.

\section{Jumlah Benih Mati}

Pada Tabel 8 dan 9 dapat di lihat jumlah benih mati tertinggi pada perlakuan umur panen benih 90 hari yaitu 6,63 perlakuan $25 \%$ kapasitas lapang pemberian air setara $900 \mathrm{ml}$ dengan jumlah benih mati 6,83 sedangkan jumlah benih mati terendah 2,94 pada umur panen 100 hari dengan kapasitas lapang setara pemberian air $3600 \mathrm{ml}$ dengan jumlah 3,00. Benih yang sampai pada akhir masa pengujian tidak keras, tidak segar, dan tidak berkecambah dikategorikan sebagai benih mati. Benih mati dapat dilihat dari keadaan benih yang telah membusuk, warna benih terlihat agak kecoklatan. Hasil uji BNT didapat perlakuan berbagai umur panen benih jagung dan kelembaban media tanam berbeda nyata terhadap jumlah benih mati dan tidak terdapat interaksi antara umur panen dan kelembaban media tanam.

\section{Tinggi Kecambah}

Pada Tabel 10, Tabel 12 dan Tabel 14 dapat dilihat bahwa tidak terdapat interaksi antara tinggi kecambah pada berbagai umur panen benih jagung dan kelembaban media tanam pada 3, 4, 5, 6 , dan 7 hari setelah tanam benih. Secara tunggal faktor perlakuan umur panen dan kelembaban media tanam berpengaruh nyata terhadap tinggi kecambah. 
Tabel 10. Tinggi Kecambah 3 HST pada Berbagai Umur Panen Benih

(Table10. Sprouts 3 Days after Transplanting at the Various Harvest Ages of Corn Seed)

\begin{tabular}{cc}
\hline Perlakuan Umur Panen Benih Jagung & Rata-rata \\
\hline 90 hari & $0,52 \mathrm{a}$ \\
100 hari & $0,78 \mathrm{a}$ \\
110 hari & $1,23 \mathrm{~b}$ \\
\hline BNT 5\% & 0,46
\end{tabular}

Keterangan : Angka yang diikuti dengan huruf yang sama pada kolom yang sama tidak berbeda nyata berdasarkan uji BNT 5\%.

Tabel 11. Tinggi Kecambah 3 HST pada Berbagai Kelembaban Media Tanam

(Table11. Sprouts 3 Days after Transplanting at the Various Humidity of Transplanting Medium)

\begin{tabular}{cc}
\hline Perlakuan Kelembaban Media Tanam & Rata-rata \\
\hline Kapasitas lapang setara pemberian air $3600 \mathrm{ml}$ & 0,76 \\
$75 \%$ Kapasitas lapang setara pemberian air $2700 \mathrm{ml}$ & 0,95 \\
$50 \%$ Kapasitas lapang setara pemberian air $1800 \mathrm{ml}$ & 0,95 \\
$25 \%$ Kapasitas lapang setara pemberian air $900 \mathrm{ml}$ & 0,71 \\
\hline
\end{tabular}

Tabel 12 Tinggi Kecambah 4 HST pada Berbagai Umur Panen Benih

(Table12. Sprouts 4 Days after Transplanting at the Various Harvest Ages of Corn Seed)

\begin{tabular}{rc}
\hline Perlakuan Umur Panen Benih Jagung & Rata-rata \\
\hline 90 hari & $5,47 \mathrm{a}$ \\
100 hari & $9,57 \mathrm{a}$ \\
110 hari & $12,60 \mathrm{~b}$ \\
\hline BNT 5\% & 0,43
\end{tabular}

Keterangan : Angka yang diikuti dengan huruf yang sama pada kolom yang sama tidak berbeda nyata berdasarkan uji BNT 5\%.

Tabel 13 Tinggi Kecambah 4 HST pada Berbagai Kelembaban Media Tanam

(Table13. Sprouts 4 Days after Transplanting at the Various Humidity of Transplanting Medium)

$\begin{array}{cc}\text { Perlakuan Kelembaban Media Tanam } & \text { Rata-rata } \\ \text { Kapasitas lapang setara pemberian air } 3600 \mathrm{ml} & 3,10 \\ 75 \% \text { Kapasitas lapang setara pemberian air } 2700 \mathrm{ml} & 2,72 \\ 50 \% \text { Kapasitas lapang setara pemberian air } 1800 \mathrm{ml} & 2,51 \\ 25 \% \text { Kapasitas lapang setara pemberian air } 900 \mathrm{ml} & 2,67\end{array}$

Tabel 14. Tinggi Kecambah 5 HST pada Berbagai Umur Panen Benih

(Table14. Sprouts 5 Days after Transplanting at the Various Harvest Ages of Corn Seed)

\begin{tabular}{rc}
\hline Perlakuan Umur Panen Benih Jagung & Rata-rata \\
\hline 90 hari & $16,92 \mathrm{a}$ \\
100 hari & $15,50 \mathrm{a}$ \\
110 hari & $20,13 \mathrm{~b}$ \\
\hline BNT 5\% & 0,60
\end{tabular}

Keterangan : Angka yang diikuti dengan huruf yang sama pada kolom yang sama berbeda nyata berdasarkan uji BNT 5\%. 
Tabel 15. Tinggi Kecambah 5 HST pada Berbagai Kelembaban Media Tanam

(Table15. Sprouts 5 Days after Transplanting at the Various Humidity of Transplanting Medium)

\begin{tabular}{cc}
\hline Perlakuan Kelembaban Media Tanam & Rata-rata \\
\hline Kapasitas lapang setara pemberian air $3600 \mathrm{ml}$ & 4,83 \\
$75 \%$ Kapasitas lapang setara pemberian air $2700 \mathrm{ml}$ & 4,36 \\
$50 \%$ Kapasitas lapang setara pemberian air $1800 \mathrm{ml}$ & 4,28 \\
$25 \%$ Kapasitas lapang setara pemberian air $900 \mathrm{ml}$ & 4,05 \\
\hline
\end{tabular}

Tabel 16. Tinggi Kecambah 6 HST pada Berbagai Umur Panen Benih

(Table16. Sprouts 6 Days after Transplanting at the Various Harvest Ages of Corn Seed)

\begin{tabular}{cc}
\hline Perlakuan Umur Panen Benih Jagung & Rata-rata \\
\hline 90 hari & $6,62 \mathrm{~b}$ \\
100 hari & $6,04 \mathrm{~b}$ \\
110 hari & $8,16 \mathrm{a}$ \\
\hline BNT 5\% & 0,86
\end{tabular}

Keterangan : Angka yang diikuti dengan huruf yang sama pada kolom yang sama berbeda nyata berdasarkan uji BNT 5\%.

Tabel 17. Tinggi Kecambah 7 HST pada Berbagai Umur Panen Benih

(Table17. Sprouts 7 Days after Transplanting at the Various Harvest Ages of Corn Seed)

\begin{tabular}{cc}
\hline Perlakuan Umur Panen benih jagung & Rata-rata \\
\hline 90 hari & $7,94 \mathrm{a}$ \\
100 hari & $7,93 \mathrm{a}$ \\
110 hari & $9,81 \mathrm{~b}$ \\
\hline BNT 5\% & 0,85
\end{tabular}

Keterangan : Angka yang diikuti dengan huruf yang sama pada kolom yang sama berbeda nyata berdasarkan uji BNT $5 \%$.

Tabel 18. Tinggi Kecambah 7 HST pada Berbagai Kelembaban Media Tanam

(Table18. Sprout 7 Days after Transplanting at the Various Humidity of Transplanting Medium)

\begin{tabular}{cc}
\hline Perlakuan Kelembaban Media Tanam & Rata-rata \\
\hline Kapasitas lapang setara pemberian air $3600 \mathrm{ml}$ & $9,45 \mathrm{~b}$ \\
Kapasitas lapang setara pemberian air $2700 \mathrm{ml}$ & $9,16 \mathrm{ab}$ \\
Kapasitas lapang setara pemberian air $1800 \mathrm{ml}$ & $8,32 \mathrm{a}$ \\
Kapasitas lapang setara pemberian air $900 \mathrm{ml}$ & $7,23 \mathrm{a}$ \\
\hline BNT $5 \%$ & 0,98
\end{tabular}

Keterangan : Angka yang diikuti dengan huruf yang sama pada kolom yang sama berbeda nyata berdasarkan uji BNT 5\%.

Tabel 19. Nisbah Pupus Akar pada Berbagai Umur Panen Benih

(Table19. Shoot Roots Ratio in the Various Harvest Ages of Corn Seed)

\begin{tabular}{rc}
\hline Perlakuan Umur Panen Benih Jagung & Rata-rata \\
\hline 90 hari & 3,75 \\
100 hari & 3,60 \\
110 hari & 3,01 \\
\hline
\end{tabular}


Tabel 20. Nisbah Pupus Akar pada Berbagai Kelembaban Media Tanam

(Table 20. Shoot Roots Ratio in the Various Humidity Medium)

\begin{tabular}{cc}
\hline Perlakuan Kelembaban Media Tanam & Rata-rata \\
\hline Kapasitas lapang setara pemberian air $3600 \mathrm{ml}$ & 3,59 \\
Kapasitas lapang setara pemberian air $2700 \mathrm{ml}$ & 3,03 \\
Kapasitas lapang setara pemberian air $1800 \mathrm{ml}$ & 4,03 \\
Kapasitas lapang setara pemberian air $900 \mathrm{ml}$ & 3,94 \\
\hline
\end{tabular}

Kecambah tertinggi pada 6 dan 7 HST yaitu pada perlakuan kelembaban media tanam dengan kapasitas air 100\%, $3600 \mathrm{ml}$ dan perlakuan kapasitas air 75\%, $2700 \mathrm{ml}$ dibandingkan dengan perlakuan kelembaban media $50 \%$ dan $25 \%$. Selama proses perkecambahan berlangsung, jaringan yang mengandung cadangan makanan karbohidrat, lemak, dan protein akan dihidrolisis dan dirubah menjadi senyawa yang sederhana dalam bentuk senyawa yang mudah diangkut. Kemudian dipindahkan ke titik tumbuh embrio dan disusun kembali ke dalam jaringan yang baru. Perlakuan umur panen menunjukkan bahwa umur tanaman 110 hari memberikan kecambah paling tinggi pada setiap pengamatan. Pada umur 110 hari, tingkat kematangan benih sudah mencapai matang fisiologis sehingga ukuran benih mencapai maksimum demikian juga dengan cadangan makanan. Benih yang berukuran besar dan berat mengandung cadangan makanan yang lebih banyak dibandingkan dengan yang kecil pada jenis yang sama. Cadangan makanan yang terkandung dalam jaringan penyimpan digunakan sebagai sumber energi bagi embrio pada saat perkecambahan. Disamping umur panen Purwadi (2011) mengemukakan juga bahwa kekurangan dan kelebihan air merupakan suatu keadaan yang tidak normal dimana tanaman mengalami suatu cekaman tertentu yang berasal dari luar tubuhnya yang dapat berupa faktor biotik maupum abiotik yang diberikan pada tanaman jagung.

\section{Nisbah Pupus Akar}

Pada Tabel 19 dan Tabel 20 tidak terdapat interaksi antara umur panen dan kelembaban media tanam terhadap nisbah pupus akar demikian juga pengaruh tunggal masing-masing umur panen benih dan pengaruh kelembaban media tanam.
Perlakuan umur panen dan Kelembaban media tanam tidak mempengaruhi nisbah pupus akar.

\section{KESIMPULAN}

Umur panen benih jagung berpengaruh nyata terhadap Daya Hantar Listrik (DHL).

Tidak terdapat interaksi antara umur panen dan kelembaban media tanam terhadap jumlah kecambah normal, abnormal, benih mati, benih keras, tinggi kecambah, dan nisbah pupus akar.

Umur panen dan kelembaban media tanam berpengaruh terhadap jumlah kecambah normal, kecambah abnormal, benih mati dan tinggi kecambah.

Jumlah benih keras dan nisbah pupus akar tidak dipengaruhi oleh umur panen benih dan kelembaban media tanam baik interaksi maupun secara tunggal.

\section{DAFTAR PUSTAKA}

Brillianti, I. P. 2009. Studi Daya Hantar Listrik dan Hubungannya dengan Mutu Fisiologis Benih Cabai (Capsicum annuum L.). Tesis. Program studi Pemuliaan Tanaman dan Teknologi Benih Fakultas Pertanian IPB Bogor.

Hermawan, F. 2011. Pengaruh Waktu Pemanenan Terhadap Produksi, Daya Berkecambah Dan Vigor Benih Cabai (Capsicum annuum L.). http://frengkyhermawan. blogspot.com/2011/06/laporan-praktikum. $\underline{\mathrm{html}}$. Diakses tanggal 25 Agustus, 2012.

Hertiningsih, A. 2009. Teknologi Benih. Penebar Swadaya. Jakarta. 
Haryati, 2008. Pengaruh Cekaman Air terhadap Pertumbuhan dan Hasil Tanaman http://library.Usu.ac.id/download/fp/hsperta nian-haryati2.Pdf. Diakses pada tanggal 5 Juli 2012

Kartasapoetra, A.G. 2003. Teknologi Benih. Rineka Cipta. Jakarta.

Muriati, E., M. Sari, dan E. Fatimah. 2008. Pengaruh Pemeramanan Buah dan Periode Simpan Terhadap Viabilitas Benih Pepaya (Carica papaya L.). Buletin Agronomi (36)(2) : 139-145.
Purwadi, E. 2011. Seleksi Benih Tahan Kering melalui Uji PEG. http://www.masbied. com.Pdf Diakses pada tanggal 11 Juli 2012.

Rahmawati, 2003. Evaluasi Mutu Benih Jagung Tingkat Petani Di Provinsi Sulawesi Selatan. Balai Penelitian Tanaman Serealia Maros. 
